\title{
Parasitic castration in Concholepas concholepas (Gastropoda: Muricidae) due to a larval digenean in northern Chile
}

\author{
Marcelo E. Oliva*, Alberto N. Olivares, Cristian D. Diaz, Mario V. Pasten \\ Facultad de Recursos del Mar, Universidad de Antofagasta, PO Box 170, Antofagasta, Chile
}

\begin{abstract}
Specimens of the edible mollusk Concholepas concholepas from Tocopilla, northern Chile, were found to be infected with larval forms of a fellodistomid digenean. Prevalence of infection did not significantly differ between male and female mollusks. A close relationship between first maturity and parasitic infection is suggested. Flukes invade gonadal and hepatopancreatic tissue and adversely affect structure and function of these organs. In heavy infections the penis was absent and destruction of the hepatopancreas was accompanied by disorganization of germinal tissue.
\end{abstract}

KEY WORDS: Marine mollusk · Concholepas concholepas - Digenea - Parasitic castration · Northern Chile Fellodistomidae

\section{INTRODUCTION}

The 'loco' Concholepas concholepas (Bruguiere 1789) (Gastropoda: Muricidae) is the most important edible mollusk of the Chilean coast, and is ecologically important in the subtidal communities in central and southern Chile (Moreno et al. 1986). Despite its importance, some aspects of the natural history of the 'loco' (an endemic species), including its parasites, are unknown. The only published work (Cañas \& Lozada 1987) regarding the parasites of $C$. concholepas includes the record of an unidentified fellodistomid which can mechanically destroy the digestive gland and the gonads. Mechanical castration by adult fellodistomids has been was described (Oliva 1992) in the marine gastropod Fissurella crassa in northern Chile. We analyze herein quantitative aspects of the process of infection and describe the histopathological alteration in the hepatopancreatic-gonadal complex (HGC) due to sporocysts of Proctoeces sp., a fellodistomid digenean fluke.

\footnotetext{
•E-mail: moliva@uantof.cl
}

\section{MATERIAL AND METHODS}

Between August-December 1994 and between January-October 1996, 12 samples of Concholepas concholepas (Table 1) were collected (irregularly over time) from shallow water ( 7 to $10 \mathrm{~m}$ depth) near Tocopilla, northern Chile $\left(22^{\circ} \mathrm{S}\right)$. In the laboratory, peristomal length (= total length) was measured (to the nearest $0.1 \mathrm{~mm}$, and each specimen was dissected and macroscopically sexed according to gonadal coloration and presence/absence of a penis. After dissection, the HGC was isolated, weighed (to the nearest $0.1 \mathrm{~g}$ ) and the widths of the HGC and gonad were measured. Portions of HGC were fixed in alcoholic Bouin fluid and processed for histology, using standard techniques, serially sectioned $(5 \mu \mathrm{m}$ thickness), and stained with hematoxylin-eosin. Prevalence of infection was calculated for male and female hosts. The following statistical analyses were performed: an analysis of variance was used to test if the mean sizes of male and female mollusks differed significantly; differences in prevalence of infection in male and female hosts were evaluated with the log likelihood ' $G$ '-test; and regression analysis detected 
Table 1. Concholepas concholepas. Number of specimens (n), size $\left( \pm \mathrm{SD}_{\mathrm{i}}\right.$ in $\left.\mathrm{mm}\right)$, and prevalence $(\mathrm{P}, \%)$ in the 12 samples collected near Tocopilla, northern Chile, in 1994 and 1996

\begin{tabular}{|lrlr|}
\hline Date & $\mathrm{n}$ & \multicolumn{1}{c}{ Size } & $\mathrm{P}$ \\
\hline $\mathbf{1 9 9 4}$ & & & \\
Aug & 48 & $97.8 \pm 2.8$ & 6.3 \\
Oct & 18 & $88.3 \pm 14.2$ & 16.7 \\
Nov & 70 & $97.3 \pm 7.3$ & 8.6 \\
Dec & 75 & $94.7 \pm 12.0$ & 14.7 \\
1996 & & & \\
Jan & 122 & $81.1 \pm 10.0$ & 3.3 \\
Feb & 72 & $90.9 \pm 9.8$ & 12.5 \\
Mar & 51 & $93.4 \pm 11.1$ & 7.8 \\
Jun & 74 & $77.6 \pm 7.93$ & 10.8 \\
Jul & 80 & $80.2 \pm 10.7$ & 12.5 \\
Aug & 85 & $84.0 \pm 9.2$ & 16.5 \\
Sep & 72 & $90.9 \pm 9.8$ & 12.5 \\
Oct & 99 & $73.4 \pm 10.3$ & 4.0 \\
\hline
\end{tabular}

relationships between mean size of mollusks and prevalence (Zar 1984, Wilkinson 1990).

\section{RESULTS}

In total, 866 specimens of Concholepas concholepas were examined, of which 413 were males and 453 females. The size of mollusks ranged from 41.4 to $120 \mathrm{~mm}$ in length. Mean lengths of males $(85.0 \mathrm{~mm}$ ) and females $(87.0 \mathrm{~mm})$ were not significantly different $\left(F_{1.864}=5.73, \mathrm{p}=0.17\right)$. From those examined, $85 \mathrm{~mol}$ lusks were parasitized by larval stages of a fellodistomid digenean, a member of the genus Proctoeces (morphological features of the metacercaria agreed well with the characteristics of the genus, as described by Bray 1983). The smallest infected male was $56.4 \mathrm{~mm}$ long and the smallest infected female was $78 \mathrm{~mm}$ long. Mean size of infected males was significantly smaller than that of females, 87.4 and $94.4 \mathrm{~mm}$ respectively $\left(F_{\mathrm{t}, 83}=7.79, \mathrm{p}=0.007\right)$. Prevalence of infection did not significantly differ between males $(9.4 \%)$ and females $(10.1 \%)(\log$-likelihood $G$-test, $G=0.123,0.50>\mathrm{p}>$ $0.75, \mathrm{df}=1$ ). Infected mollusks were easily detected macroscopically because the color pattern of infected gonads was altered: healthy male and female gonads were yellow and white respectively, whereas infected gonads showed the typical orange coloration of sporocysts. Prevalence of infection was significantly and positively associated with host size (Pearson I correlation coefficient, after angular transformation of prevalence data, $r=0.76, F=11.22, p=0.01, d f=8$ ). Mean intensity and abundance were not evaluated because the large number of sporocysts precluded analysis.

\section{Normal histology}

Concholepas concholepas is dioecious. Male and female gonads are closely associated with the digestive gland. Gonadal and hepatopancreatic tissues were separated by a thin layer of connective tissue (Fig. 1). Externally, the testes and the ovary were surrounded by a fibro-collagen connective tissue. Branches of this tissue give rise to internal projections into the gonads; these projections themselves branch and form septa, which define compartments containing gametes at different developmental stages (Huaquin 1979).

The hepatopancreas includes numerous follicles attached to the connective tissue. Each lobe contains numerous acini and excretory ducts. Acini include goblet cells with chromofugue vacuoles, prismatic cells with eosinophilic granules, and cylindrical and agranular cells (Fig. 2).

\section{Histopathology}

Sporocysts were found within the layer of connective tissue of the hepatopancreas (Fig. 3). As the infection developed, parasites progressively invaded the connective tissue, and the glandular and gonadal tissue became compressed (Fig. 4). The width of the gonads of heavily infected mollusks was, on average, only $33 \%$ of the width of a healthy gonad. In addition to this mechanical action, structural disorganization of glandular acini became evident. Acini were smaller than those of uninfected tissue; cells became vacuolated and the acidophilic and basophilic contents of cells were not able to be seen (Fig. 5). Chromofugue cells were not altered. Additionally, with the development

Figs. 1-8. Concholepas concholepas. Fig. 1. Transverse section of a healthy hepatopancreatic-gonadal complex. Et: external tunica; Ov: ovary; and Hp: hepatopancreas. HE, 429x. Fig. 2. Non-infected hepatopancreas. Pancreatic acinus surrounded by connective tissue (arrow). G: Goblet cells; P: prismatic cells containing eosinophilic granules. HE, 1716x. Fig. 3. Sporocyst (arrow) located inside the layer of connective tissue of the hepatopancreas. HE, 429x. Fig. 4. Compressed hepatopancreas (Hp) and gonads (Go) caused by invasion of connective tissue by sporocysts (arrow). HE, 429x. Fig. 5. Altered structure of hepatopancreas due to heavy infection (compare with Fig. 2). HE, 1716x. Fig. 6. Altered testis. No germinal line is present. Only a few nerotic germinal cells are present (arrows). HE, 1716x. Fig. 7. Heavy infection. Gonadal tissue completely absent (compare with Fig. 1).

HE, 429x. Fig. 8. Metacercanae (Fellodistomidae) encysted between hepatopancreatic acini. HE, 429x 


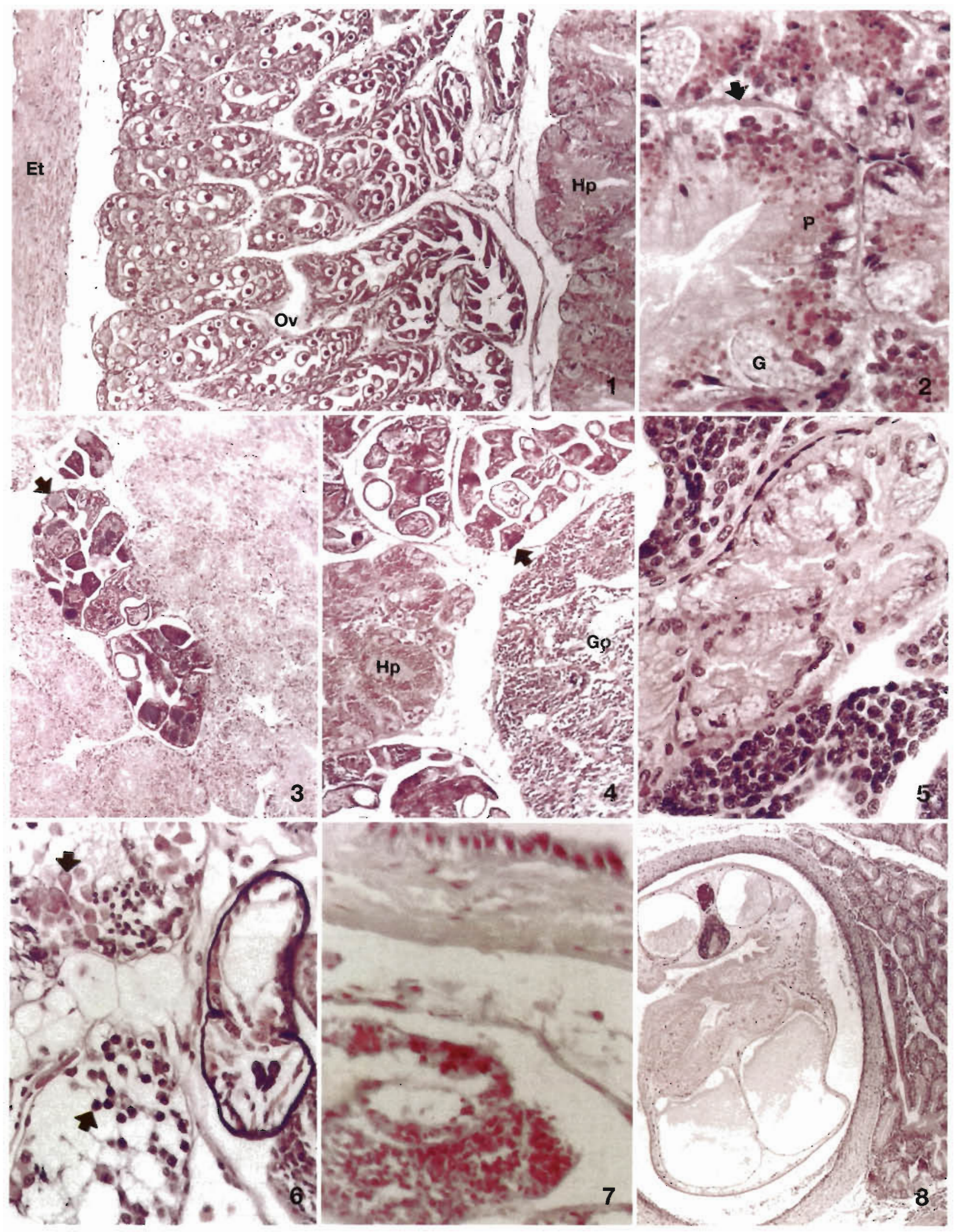


of the parasitic infection, gonadal parenchyma became compressed. In heavy infections, destruction of the hepatopancreas was accomplished by disorganization of germinal tissue of the gonads. Germinal tissues disappeared and total castration was evident (Figs. 6 \& 7). Macroscopically, gonads were not recognizable as independent organs and frequently the reproductive ducts and accessory glands appeared atrophied.

\section{DISCUSSION}

The only previous record of parasites in the 'loco' is that of Cañas \& Lozada (1987), who found different developmental stages of a fellodistomid, including adult flukes, in a sample of 32 specimens from a markrecapture experiment in Caldera (ca $650 \mathrm{~km}$ south from Tocopilla). Mostly sporocysts were found in our samples; however, a single metacercaria (Fellodistomidae) was found encysted between hepatopancreatic acini (Fig. 8). In contrast to other gastropod-parasite systems with sporocysts or rediae as the infective stage, Concholepas concholepas is infected by only 1 parasitic digenean. (Sullivan et al. 1985, Fernández \& Esch 1991a, Jokela \& Lively 1995, Sokolova 1995). Parasites of other marine gastropods from this zone are also only infected by 1 parasitic species; this has been found to be the case in 5 species of key-hole limpets Fissurella spp. (Oliva \& Díaz 1988, 1992), suggesting an impoverished pattern of infection similar to those described for marine teleost fishes in central Peru and northern Chile (Oliva et al. 1996).

As in other mollusks (Sokolova 1995, Taskinen \& Valtonen 1995), there were no significant differences in prevalence of infection between male and female mollusks. A direct relationship between prevalence of infection and size of molluskan host has been described for infection by larval digeneans (Sousa 1983, Taskinen \& Valtonen 1995), and adult digeneans (Oliva \& Diaz 1988, 1992). Length-frequency distribution and statistical analysis (Fig. 9) indicated that the proportion of infected mollusks increased with size. The infection is apparently closely related to first maturity. The smallest infected male was $56.4 \mathrm{~mm}$ and the smallest infected female $78 \mathrm{~mm}$. This difference is related to the size at the first maturity. Our results shows that first maturity $150 \%$ of mature specimens) is reached at $57 \mathrm{~mm}$ for males (smallest mature $51.4 \mathrm{~mm}$, largest immature $62.2 \mathrm{~mm}$ ) and $72 \mathrm{~mm}$ for females (smallest mature $69.6 \mathrm{~mm}$, largest immature $75.7 \mathrm{~mm}$ ).

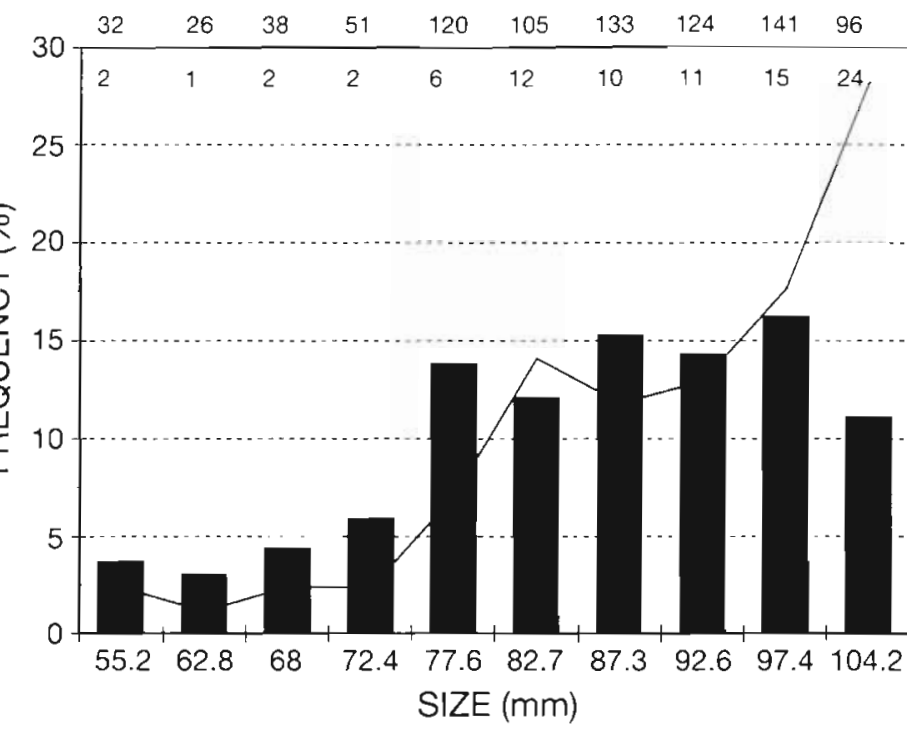

ig. 9. Concholepas concholepas. Length-frequency distribution of nonnfected (bars) and infected (line) 'loco'. Numbers at top of graph indiate number of non-infected (upper) and infected (lower) mollusks in each size class

Digenean flukes as a typical parasitic group influence the population dynamics of the host in 2 ways: first by inducing mortality (directly or indirectly by modifying host behavior); or second by castrating the host (ecological death) (Hurd 1990, Huxham et al. 1993). Apparently, both mechanisms have never previously been described as occurring simultaneously in a host species. Gigantism in mollusks (enhanced host growth), due to castrator parasites, can occur naturally and experimentally (Sousa 1983, Fernández \& Esch 1991b). Our results show that induced mortality and castration can occur simultaneously in the same population if the effect of the same parasitic species induces alteration in different organs and/or tissue. The development of infection in the digestive gland causes disfunction; no secretion (i.e. digestive function) occurs. This alteration in the glandular function will inevitably lead to the death of the host. Furthermore, while the infection in the digestive gland develops, the level of castration increases with germinal tissue compression.

\section{LITERATURE CITED}

Bray RA (1983) On the fellodistomid genus Proctoeces Odhner, 1911 (Digenea), with brief comments on two other fellodistomid genera. J Nat Hist 17:321-339

Cañas P, Lozada E (1987) Nota sobre un trematode digeneo endoparasitico del loco Concholepas concholepas Bruguiere 1789 (Gastropoda: Muricidae). Parasitol Día 11: $173-176$

Fernández J, Esch G (1991a) Guild structure of larval trematodes in the snail Helisoma anceps: patterns and processes at the individual host level. J Parasitol 77.528-539 
Fernández J. Esch G (1991b) Effect of parasitism on the growth rate of the pulmonate snail Helisoma anceps. J Parasitol 77:937-944

Huaquin L (1979) Análisis histológico del ovario de Concholepas concholepas (Bruguiere 1789) (Gastropoda:Muricidae). Biol Pesq (Chile) 12:71-77

Hurd H (1990) Physiological and behavioural interactions between parasites and invertebrates hosts. Adv Parasitol 29:271-318

Huxham MD, Raffaeli D, Pike A (1993) The influence of Cryptocotyle lingua (Digenea: Platyhelminthes) infections on the survival and fecundity of Littorina littorea (Gastropoda: Prosobranchia): an ecological approach. J Exp Mar Biol Ecol 168:223-238

Jokela J, Lively CM (1995) Spatial variation in infection by digenetic trematodes in a population of freshwater snails (Potamopyrgus antipodarum). Oecologia 103:509-517

Moreno CA, Lunecke KM, Lepez MI (1986) The response of an intertidal Concholepas concholepas (Gastropoda) population to protection from man in southern Chile and the effects on benthic sessile assemblages. Oikos 46:359-364

Oliva M (1992) Parasitic castration in Fissurella crassa (Archaeogastropoda) due to an adult digenea, Proctoeces lintoni (Fellodistomidae). Mem Inst Oswaldo Cruz 87:37-42

Oliva ME, Díaz M (1988) Aspectos cuantitativos de la infección por Proctoeces humboldti (Trematoda: Fellodistomidae) en la lapa Fisurella crassa (Mollusca: Archaeogastropoda). Rev Chil Hist Nat 61:27-33

Editorial responsibility: Albert Sparks,

Seattle, Washington, USA
Oliva ME, Díaz M (1992) An ecological approach to the study of infection of Proctoeces Iintoni (Digenea, Fellodistomidae) in the key hole limpet, Fissurella limbata Sowerby, 1835 (Archaeogastropoda) from northern Chile. Acta Parasitol Pol 37:115-118

Oliva ME, Castro RE, Burgos R (1996) Parasites of the flatfish Paralichthys adspersus (Steindachner, 1867) (Pleuronectiformes) from northern Chile. Mem Inst Oswaldo Cruz 91 301-306

Sokolova IM (1995) Influence of trematodes on the demography of Littorina saxatilis (Gastropoda: Prosobranchia Littorinidae) in the White Sea. Dis Aquat Org 21:91-101

Sousa WP (1983) Host life history and the effect of parasitic castration on growth: a field study of Cerithidea californica Haldeman (Gastropoda: Prosobranchia) and its trematode parasites. J Exp Mar Biol Ecol 73:273-296

Sullivan JT, Cheng TC, Howland KH (1985) Studies on parasitic castration: castration of llyanassa obsoleta (Mollusca: Gastropoda) by several marine trematodes. Trans Am Microsc Soc 104:154-171

Taskinen J, Valtonen ET (1995) Age-, size-, and sex-specific infection of Anodonta piscinalis (Bivalvia: Unionidae) with Rhipidocotyle fennica (Digenea: Bucephalidae) and its influence on host reproduction. Can J Zool 73:887-897

Wilkinson L (1990) SYSTAT: the system for statistics. SYSTAT, Inc, Evanston, IL

Zar HJ (1984) Biostatistical analysis, 2nd edn. Prentice Hall, Upper Saddle River, NJ

Submitted: December 1, 1997; Accepted: October 19, 1998 Proofs received from author(s): March 30, 1999 